\title{
Enclosures in West Pokot, Kenya: Transforming land, livestock and livelihoods in drylands
}

Gert Nyberg $^{1 *}$, Per Knutsson ${ }^{2}$, Madelene Ostwald ${ }^{3,4}$, Ingrid Öborn ${ }^{5,6}$, Ewa Wredle ${ }^{7}$, David Jakinda Otieno ${ }^{8}$, Stephen Mureithi ${ }^{9}$, Peter Mwangi ${ }^{10}$, Mohammed Y. Said ${ }^{11}$, Magnus Jirström ${ }^{12}$, Antonia Grönvall', Julia Wernerssonn ${ }^{2,13}$, Sara Svanlund ${ }^{1}$, Laura Saxer ${ }^{2}$, Lotje Geutjes ${ }^{2}$, Vera Karmebäck ${ }^{8,12}$, John N. Wairore ${ }^{9}$, Regina Wambui ${ }^{10}$, Jan De Leeuw ${ }^{6}$ and Anders Malmer

\begin{abstract}
Dryland livestock production systems are changing in many parts of the world, as a result of growing human populations and associated pressure on water and land. Based on a combination of social and natural science methods, we studied a 30-year transformation process from pastoralism to a livestock-based agro-pastoral system in northwestern Kenya, with the overall aim to increase the understanding of the ongoing transition towards intensified agro-pastoralist production systems in dryland East Africa.

Key to this transformation was the use of enclosures for land rehabilitation, fodder production, and land and livestock management. Enclosures have more soil carbon and a higher vegetation cover than adjacent areas with open grazing. The level of adoption of enclosures as a management tool has been very high, and their use has enabled agricultural diversification, e.g. increased crop agriculture, poultry production and the inclusion of improved livestock. Following the use of enclosures, livelihoods have become less dependent on livestock migration, are increasingly directed towards agribusinesses and present new opportunities and constraints for women. These livelihood changes are closely associated with, and depend on, an ongoing privatization of land under different tenure regimes.

The results indicate that the observed transformation provides opportunities for a pathway towards a sustainable livestock-based agro-pastoral system that could be valid in many dryland areas in East Africa. However, we also show that emergent risks of conflicts and inequalities in relation to land, triggered by the weakening of collective property rights, pose a threat to the sustainability of this pathway.
\end{abstract}

Keywords: Enclosure, Transformation, Land use, Livestock, Livelihood, Intensification, Agro-pastoralism, Kenya

\section{Background}

Changing livestock production systems in East African dryland

Drylands cover around $40 \%$ of the world, host nearly one third of its human population and $50 \%$ of the world's livestock and have traditionally been used and managed by pastoralists through communal or common property rights-based land tenure systems (McDermott et al. 2010; United Nations Environment Management Group 2011). In sub-Saharan Africa (SSA), $40 \%$ of the

\footnotetext{
* Correspondence: Gert.Nyberg@slu.se

${ }^{1}$ Department of Forest Ecology and Management, SLU, SE-901 83 Umeå, Sweden

Full list of author information is available at the end of the article
}

total available land is utilized by 25 million pastoral and 240 million agro-pastoral farmers, with livestock as the primary source of livelihoods (Neely et al. 2009). In Kenya, a substantial part of the expected population increase from 38.6 million in 1999 to some 66 million (http://esa.un.org/ wpp/unpp/p2k0data.asp) in 2030 is expected to take place in drylands and in dryland urban centres.

Many dryland areas have a history of economic and political marginalization of pastoralist communities relying on degraded lands with low productivity, recurrent famines and resources conflicts (Opiyo et al. 2011). So far, most government development policies related to pastoralism in Africa have been based on the paradigm of a Tragedy of the Commons (Hardin 1968), considering pastoralism as a form 
of land use that is mismanaging dryland resources and being responsible for land degradation through overgrazing of communal rangelands (Ayantunde et al. 2011). Against this historical backdrop, dryland areas face a multitude of challenges, including climate variability and change, an accelerated demand for livestock products due to human population growth, continuing urbanization and changing food preferences, limited possibilities of increasing livestock productivity, and increasing pressure from the expansion of agriculture into grazing lands (Catley et al. 2013; McDermott et al. 2010; Mortimore et al. 2009; Sumberg and Thomson 2013; Thornton 2010). There is subsequently a need for sustainable intensification of livestock production in the subSaharan drylands (Havlik et al. 2014; Herrero et al. 2012).

One of the most powerful ideas to emerge in relation to the need for sustainable intensification in the drylands is the Livestock Revolution (Delgado et al. 1999) denoting the ongoing and projected accelerated growth in demand for livestock products in the developing world due to human population growth, rising incomes, continuing urbanization and changing food preferences. With expectations of better nutrition and health as well as an effective pathway towards ecologically sustainable poverty alleviation of hundreds of millions of small-scale producers, the Livestock Revolution describes a general transition characterized by a trajectory from a) nomadic to sedentary lifestyles and production systems; b) subsistence to intensified, commercial production; and c) collective to private land tenure (Delgado et al. 1999; McDermott et al. 2010; Sumberg and Thomson 2013). Recent research confirms rapid and dynamic transition processes towards intensified, as well as diversified, agropastoralist production systems in East African drylands. Driven by local needs to adapt to demographic pressures and the subsequent need to intensify the use of limited land and water resources, the emerging agro-pastoralist systems are responding to technological advancements, changing governance structures and emerging market opportunities based on a diverse and wide range of alternative livelihood strategies (often pursued in combination), including commercial farming; increased marketing of livestock, dairy products and hides; entrepreneurship through different types of businesses and shops, wage labour and salaried employment; and petty commodity trade (Beyene 2009; Catley et al. 2013; Gichero et al. 2012; Greiner et al. 2013; Lambin et al. 2003; Mwangi 2007; Wangui 2014; Woodhouse 2003). However, the extent to which the observed transition processes constitute a pathway to sustainable intensification of drylands is an intensively debated question (e.g. Beyene 2014; Catley et al. 2013; Greiner et al. 2013; Schmidt and Pearson 2016).

\section{Enclosures}

An increasingly common feature of land use change in dryland Sub-Saharan Africa is the enclosing of land in order to, for example, increase productivity of livestock and alleviate poverty (Mureithi et al. 2015; Verdoodt et al. 2010), protect crops, arrest land degradation and improve carbon (C) sequestration (Lal 2004; Mekuria et al. 2011). The practice of enclosures in East Africa covers a wide range of management techniques from the physical fencing off of smaller parcels of land for private or communal (Damene et al. 2013; Mureithi et al. 2015; Verdoodt et al. 2010; Wairore et al. 2015a; Yaynshet et al. 2009) purposes to more implicit social contracts regarding the use of larger areas of communal land (Barrow 2014; Monela et al. 2005), also common in West Africa (Moritz 2012). In some areas, enclosures constitute a traditional management tool, and in other areas, enclosures were introduced in order to rehabilitate degraded rangelands. What is new, however, is the increasingly common use of enclosures as a way of privatizing communal land, driven by a combination of increasing restrictions on livestock mobility due to population increase, emerging and expanding markets for livestock and agricultural products, and conflicts around resources in arid and semi-arid areas (Bernstein et al. 2003; Beyene 2009; Catley et al. 2013; Napier and Desta 2011; Woodhouse 2003).

The practice of enclosing communal land can be seen as an important management tool for sustainable intensification of drylands within the general framework of a marketdriven livestock revolution (Angassa and Oba 2010; Catley et al. 2013; McDermott et al. 2010; Verdoodt et al. 2010; Woodhouse 2003). For example, considering the vast areas of drylands and their current state of degradation, there is a huge potential to sequester $C$ into these systems and simultaneously make them more productive (Neely et al. 2009). In Africa, $59 \%$ of the total C stock is held in drylands (Campbell et al. 2008; UNEP 2008). Improvements in rangeland management, for example, through enclosures, have the potential to sequester 1.3 to 2 gigatonne carbon dioxide equivalents (Gt $\mathrm{CO}_{2} \mathrm{eq}$ ) worldwide to 2030 (Smith et al. 2007). However, to be able to include livestock-based agropastoral drylands into the international $\mathrm{C}$ sequestration discourse and the associated potential payment schemes, a detailed understanding of $\mathrm{C}$ dynamics in different forms of enclosure management regimes is needed.

As an estimated $70 \%$ of the world's poorest rely on income from pastoralism and agro-pastoralism, changes in vegetation and its associated ecosystem functions through the use of enclosures will have an immediate effect on their livelihoods (Thomas 2012). Vegetation ecological dynamics in drylands are often referred to as following either equilibrium or nonequilibrium paradigms, where the former largely is governed by biotic factors, such as grazing pressure and partial rest, while the latter is governed by abiotic factors like rainfall and especially the variability of rainfall. However, these two paradigms might not be entirely exclusive (Briske et al. 2003; Müller et al. 2007; Vetter 2005). Wildlife numbers decreased by $67 \%$ between 1977 and 2013 in Kenyan rangelands in general and by $98.5 \%$ in West Pokot. Simultaneously, there 
has been a decrease by $26 \%$ of cattle and a slight increase (4. \%) in goats and sheep in West Pokot (Ogutu et al: Extreme wildlife declines and concurrent increase in livestock numbers in Kenya rangelands, submitted). The livelihood implications of enclosures have been a topic for a number of recent case studies across East Africa and indicate negative social impacts in terms of erosion of traditional, collective property rights, emergence of conflicting interests over land and water resources and a gradual transfer of assets from poor to wealthier households (Angassa and Oba 2008; Beyene 2009; Beyene 2010; Lesorogol 2008; Napier and Desta 2011; Woodhouse 2003). In order to overcome the present fragmented state of knowledge on enclosures, where potential ecological and economic benefits are contrasted with the fear of negative social consequences, there is a need for multi-disciplinary research with a capacity to uncover situation-specific human and socio-environmental dynamics of emerging agro-pastoralist systems.

\section{Aim and objectives}

This paper presents results from a multi-disciplinary analysis based on the Livestock Revolution trajectories (Delgado et al. 1999) that explores the role of enclosures in a 30-year transformation process of land, livestock and livelihoods in dryland West Pokot, Kenya. We hypothesize that the use of enclosures as a land management tool is key in this process and, as consequence, argue that the management of the enclosures is of fundamental importance for the sustainability of this transformation. The overall aim is to contribute to the general understanding of the ongoing transition from pastoral systems towards intensified, agro-pastoralist production systems in dryland East Africa. The paper is guided by the following specific objectives to:

1. Quantify the extent, management and use of enclosures

2. Determine the effect of enclosures on vegetation cover, plant productivity, plant diversity and soil organic matter

3. Explore how the transformation of land through the use of enclosures relates to changes in livelihoods.

\section{Study area}

The study area, West Pokot County, is located in northwest Kenya and bordering Uganda (Figure 1). Since 2013, West Pokot is one of the 47 counties in Kenya that

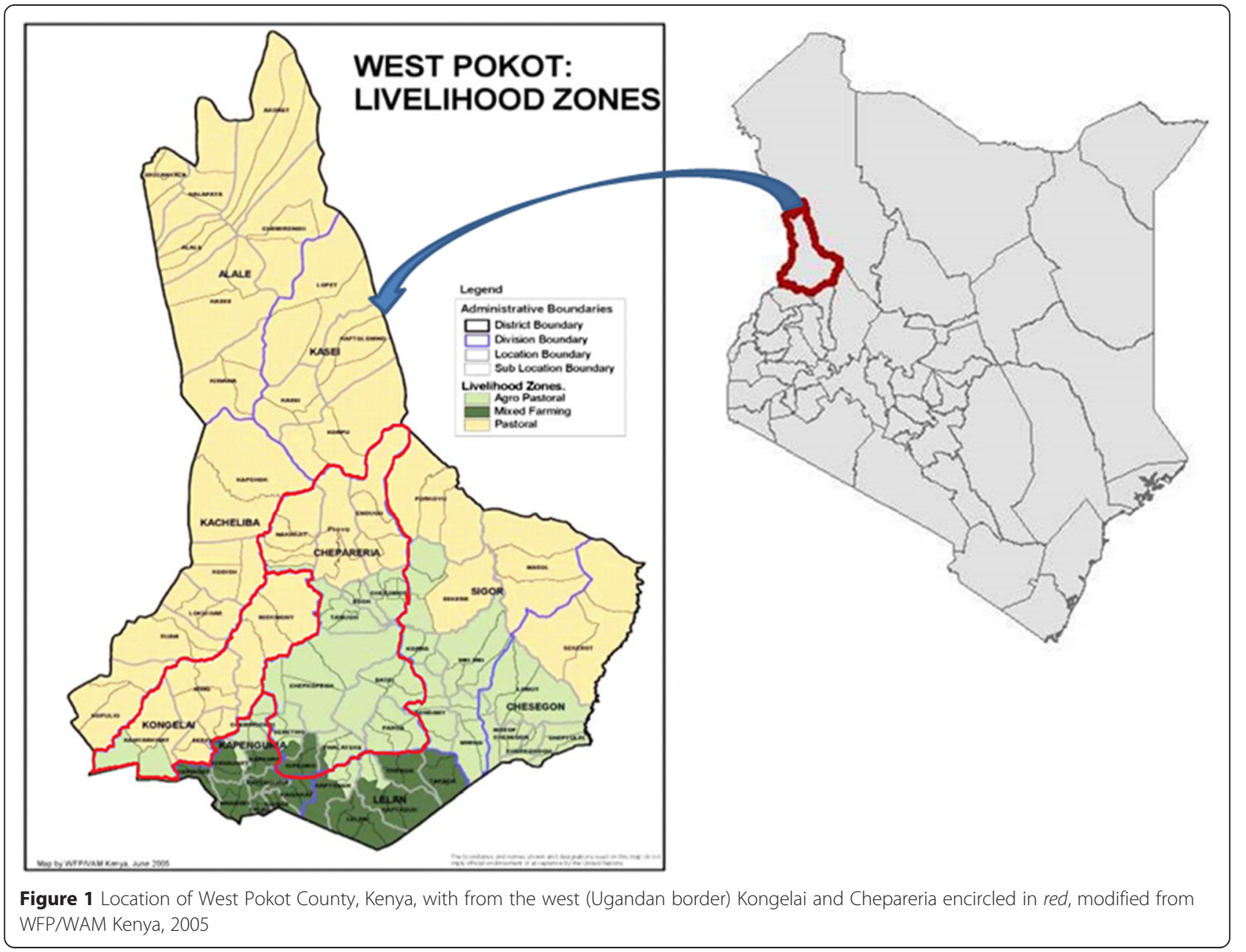


were established by the 2010 Constitution of Kenya. The county has a population of 512,690 (2009 census) and an area of $8,418 \mathrm{~km}^{2}$ (County Government of West Pokot 2013). West Pokot has very varied altitudes and thereby large variation in climate and agro-ecological zones. The rainfall varies from $400 \mathrm{~mm}$ (lowlands) to $1,500 \mathrm{~mm}$ (highlands) per annum, and the annual mean temperature ranges from a minimum of $10{ }^{\circ} \mathrm{C}$ to a maximum of $30{ }^{\circ} \mathrm{C}$ in different parts of the county (http://www.westpokot.go.ke/). The dominant farming and livelihood system in major parts of West Pokot is pastoralism, while in the southern-central parts with higher altitudes and more rainfall agro-pastoralism and mixed farming is common (NDMA 2014; Figure 1).

In the late 1980 s, the non-governmental organization (NGO) Vi Agroforestry introduced enclosures and agroforestry for land rehabilitation and increased productivity in Chepareria division in West Pokot (Makokha et al. 1999). West Pokot is a pastoralist region facing challenges such as increased food demand because of growing population and changes in consumption patterns, climate change, water scarcity and globalization. Adoption was initially slow, but after some successful demonstrations and intensive extension, the new practices were widely adopted by local livestock owners. This coincided with land tenure changes, i.e. more individualized land user rights (Wairore et al. 2015b) Nowadays, 30 years later, enclosures dominate the landscape in Chepareria. In the neighbouring division of Kongelai, the Vi Agroforestry initiative came in later, with less intensity and shorter duration. Much of the development seen in Chepareria is largely unseen in Kongelai. In both divisions, the NGO activities were phased out in 2001 (Kitalyi et al. 2002).

Local residents, authorities and development workers all testify that following the introduction of enclosures there have been dramatic changes in land use. This has been seen through increase in vegetation cover and decrease in land degradation and in livestock management with more enclosures for regulated grazing and introduction of improved breeds. During the same period, the area has undergone rapid development of infrastructure through roads, markets and primary as well as secondary schools. Enclosure of land for restoration, protection and management of pasture (with individual land tenure) in the drylands of West Pokot could be one driver of socio-economic development.

The field studies have mainly focused on the central and western parts of West Pokot - the division of Chepareria with reference studies carried out in the division of Kongelai (Figure 1). In Chepareria, the studies cover the villages Yewaleteke, Pserum, Morbus and Chepkopegh. The field study areas are all located in the lowlands of West Pokot where the altitudes are between 1,100 and $1,500 \mathrm{~m}$ above sea level. The altitudes in Kongelai are somewhat lower than Chepareria. In the field study areas, the rainfall is bimodal with annual precipitation of 700 to $1,000 \mathrm{~mm}$.

\section{Methods \\ Research for development platform on Land, Livestock and Livelihood (Triple L)}

Triple L (Land, Livestock and Livelihood, www.triplel.se) is a research for development platform with focus on transformation of East African drylands and was initiated 2013. Triple L consists of national and international researchers, local authorities, development workers (NGO), farmer representatives and extensionists (field advisors), and the platform has organized stakeholder workshops, field visits, capacity development and initiated students' research projects. This paper is a result of the Triple $\mathrm{L}$ workshops and research projects carried out in West Pokot 2013 to 2014. Population and rainfall data was collected from the Kenya National Bureau of Statistics (http://www.knbs.or.ke/).

\section{Vegetation and land use change assessment}

To assess a possible change in vegetation over time (2001 and 2014) and between places (Chepareria and Kongelai), 24 MODIS (MOD13Q1) Normalized Difference Vegetation Index (NDVI) satellite images were collected from the USGS Earth Explorer database at a spatial pixel resolution of $250 \mathrm{~m}$ as 16-day composites, consisting of the highest value for each pixel over a 16day period. Twelve images, one from each month, were used for each year to get the whole vegetation cycle. The NDVI is a normalized ratio of the near infrared (841 to $876 \mathrm{~nm}$ ) and red (620 to $670 \mathrm{~nm}$ ) bands, which is often used as an index to reveal seasonal and/or inter-annual changes in vegetation. Due to the strong relationship between NDVI and vegetation production, NDVI can be used as a proxy for net primary production (NPP) (Fensholt and Proud 2012). The NDVI range is from -1 to 1 and is related to the chlorophyll activity, which can be an effect of increased density or cover giving a higher NDVI value. The vegetation definition used in this assessment refers to vegetation at large without excluding any primary vegetation production process, meaning that not only enclosures are assessed. To identify areas of increased or decreased vegetation in the areas, pixels of yearly NDVI sums and mean were compared between 2001 and 2014. This gives an indication of change without quantifying how large the change is (Ostwald et al. 2007). Further, mean and standard deviation (st.dev) of the NDVI value were calculated for the 2 years and between the two areas. 


\section{Field studies}

\section{Use of enclosures}

Data on the use of enclosures was collected using questionnaires administered to 20 randomly selected households from each of the four villages in Chepareria division $(n=80)$. The households were selected based on a list of all households in each village, provided by local chiefs.

\section{Land use, livestock, vegetation and carbon analyses}

To assess the land use within the enclosures, farm size and number of livestock per household semi-structured interviews $(n=120)$ in the same four villages in Chepareria division were administered during 2014. Respondents and enclosures were randomly chosen from lists of farmers with enclosures.

Vegetation assessments within $(n=17)$ and outside $(n=12)$ enclosures were done in $101-\mathrm{m}^{2}$ random plots for vegetation cover (\%) and in the same $101-\mathrm{m}^{2}$ plots, in $210-\mathrm{m}^{2}, 1100-$ $\mathrm{m}^{2}$ and 1 1,000- $\mathrm{m}^{2}$ plots within Modified Whittaker plots (Stohlgren et al. 1995). Soil samples from different age classes of enclosures $(0=$ open grazing, 2 to 5 years, 7 to 12 years, $>15$ years) were taken, and one sample consisted of a composite of three samples from each plot, in six replicates. For carbon analyses, soil samples were in 20-cm intervals down to 1$m$ depth and was analysed by mid-infrared (MIR) spectrometry (Bruker Tensa 27) at the ICRAF laboratory in Nairobi (Aynekulu et al. 2011). Also, the soil study assessed vegetation cover (in \%) in $100-\mathrm{m}^{2}$ plots around the soil sampling spots, $n=18$ inside respective $n=6$ outside enclosures. Enclosures were randomly chosen in different age categories from $\mathrm{Vi}$ Agroforestry lists, and the adjacent open area was chosen as reference. Statistical differences were analysed with SPSS.

\section{Livelihood changes}

We have qualitatively analysed changes in livelihood strategies through 131 semi-structured interviews (60\% with men and $40 \%$ with women) and seven focus group
Table 1 Population development in West Pokot; note that discrepancies, marked italic, are due to changes in division/ location boundaries

\begin{tabular}{ccccccc}
\hline & 1960 & 1970 & 1979 & 1989 & 1999 & 2009 \\
\hline Population & & & & & & \\
Kongelai & 7,616 & 14,002 & 24,895 & 35,128 & 20,076 & 27,527 \\
Chepareria & 10,738 & 19,901 & 35,531 & 50,566 & 68,003 & 41,563 \\
West Pokot & 50,828 & 91,883 & 162,210 & 229,917 & 307,194 & 512,690 \\
Population density (persons/(km²) & & & & \\
Kongelai & 10 & 19 & 34 & 48 & 27 & 38 \\
Chepareria & 7 & 13 & 24 & 34 & 45 & 28 \\
West Pokot & 6 & 10 & 18 & 26 & 35 & 58 \\
\hline
\end{tabular}

interviews (four with only women and three with only men) in Chepareria division conducted between 2012 and 2014. Semi-structured interviews as a method made it possible to comparatively address the same themes and concepts across ecological zones, administrative boundaries and socio-economic conditions, while still allowing for probing into individual experiences and perceptions. The focus group interviews provided a tool for stimulating a discussion on changing livelihoods and gender roles with a focus on both female and male experiences (Bryman 2012).

\section{Results}

\section{Population development}

Population increase in dryland related to rainfall indicates the pressure on land. Machakos County had similar population densities in 1979 as West Pokot in 2009 (Figure 2).

In West Pokot, the population has increased tenfold in West Pokot between 1960 and 2009, and it has more than doubled between 1989 and 2009, (Table 1) in contrast to a fivefold increase in national population during the same period (from 8 million to about 40 million 1969 to 2009). West Pokot County population shows a continuous

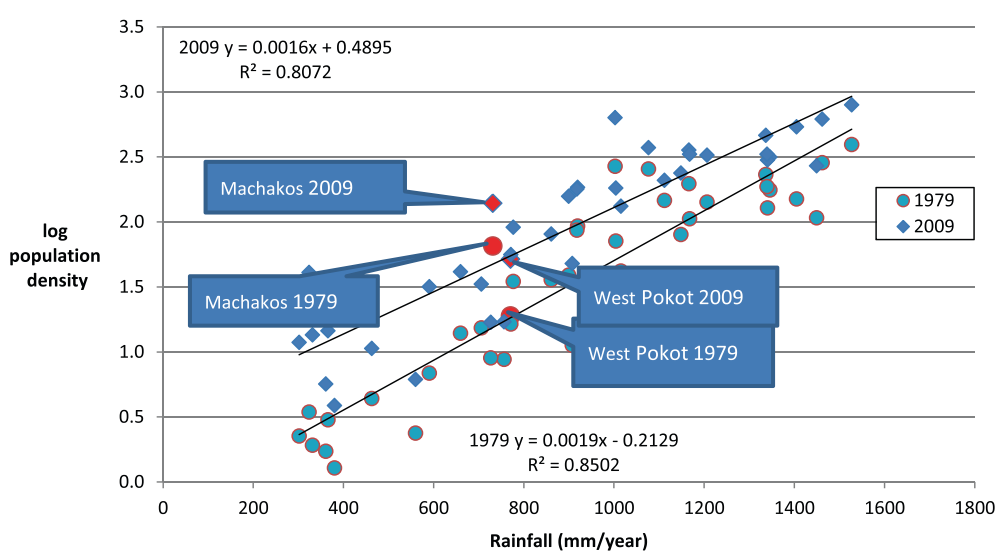

Figure 2 Log population densities (y-axis) versus annual rainfall (mm/year, $x$-axis) in Kenyan districts/counties (Nairobi and Mombasa excluded) in 1979 and 2009. Note that West Pokot is in 2009 where Machakos was in 1979 in terms of population density. The lower regression line is for 1979, the upper for 2009 
increase unlike discrepancies in divisional populations (Table 1) which are caused by changes in internal administrative boundaries.

\section{Vegetation and land use change}

From the MODIS NDVI analysis, it is possible to see a change in vegetation (chlorophyll activity) from 2001 to 2014 (Figure 3 ); only $5 \%$ of the area is the same in terms of vegetation in 2014 as compared to 2001 (Table 2). The environment has seen an increase in vegetation over $82 \%$ in this part of West Pokot, where Chepareria and Kongelai have 86 and $75 \%$, respectively (Table 2). The area of decreased vegetation is concentrated around the mountain areas. Kongelai has a decrease of vegetation in $19 \%$ of the area as compared to Chepareria that only has a decrease in $10 \%$ of the area. Hence, this area of West Pokot has experienced a general increase in chlorophyll activities since 2001, which could have several causes that we are not able to single out here. Changes in rainfall patterns, temperature, land use or management are all likely drivers to this vegetation change.

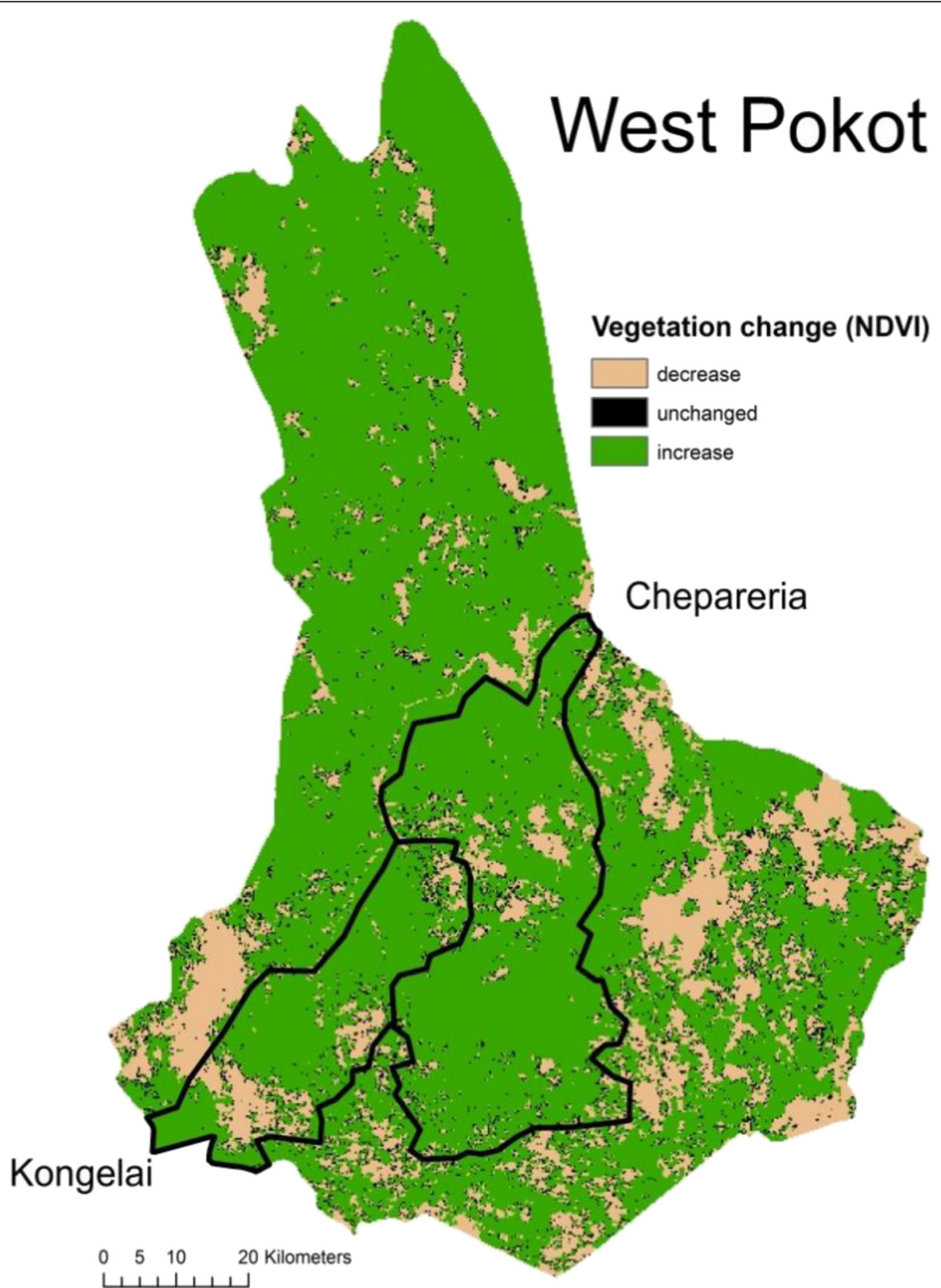

Figure 3 Change in vegetation (chlorophyll activity) in West Pokot from 2001 to 2014 based on NDVI analysis of 24 MODIS images (one from each month). Image pixel size $250 \mathrm{~m}$ 
Table 2 Vegetation index analysis between Chepareria, Kongelai and both districts for 2001 and 2014 (total sum and mean)

\begin{tabular}{llll}
\hline & Chepareria & Kongelai & Both areas \\
\hline $\mathrm{km}^{2}$ & 1,525 & 762 & 2,287 \\
Change in NDVI from & & & \\
2001 to $2014\left(\mathrm{~km}^{2}(\%)\right)$ & & & \\
$\quad$ Decreased & $148(10)$ & $145(19)$ & $294(13)$ \\
$\quad$ Unchanged & $65(4)$ & $47(6)$ & $112(5)$ \\
Increased & $1,312(86)$ & $571(75)$ & $1,881(82)$ \\
NDVI 2001 (total sum) mean & 6.04 & 5.12 & 5.73 \\
$\quad$ St.dev & 1.26 & 1.22 & 1.54 \\
NDVI 2001 (mean) mean & 0.5 & 0.43 & 0.48 \\
$\quad$ St.dev & 0.11 & 0.1 & 0.13 \\
NDVI 2014 (total sum) mean & 6.57 & 5.41 & 6.19 \\
$\quad$ St.dev & 1.2 & 1.12 & 1.3 \\
NDVI 2014 (mean) mean & 0.55 & 0.45 & 0.52 \\
$\quad$ St.dev & 0.1 & 0.09 & 0.11 \\
\hline
\end{tabular}

NDVI values range from -1 to 1

The NDVI values in Kongelai are lower than in Chepareria and in both divisions combined for both total sum and mean for both the years (Table 2). As indicated by the change analysis, there is an increase in the total sum and mean of NDVI from 2001 to 2014. The difference is greater in 2014 (mean of 2014 mean: 0.55 in Chepareria and 0.45 in Kongelai) than in 2001 (0.5 in Chepareria and 0.43 in Kongelai). The mean values are higher in Chepareria than in Kongelai, even in 2001, meaning that the difference in vegetation between the two divisions is older than 2001. The causes have to be sought from processes before 2001, where the enclosure introduction in the 1980s is one possible explanation. The standard deviations are overall greater in Chepareria than in Kongelai, which indicates that there is a higher variety or spread of vegetation intensity in Chepareria.

Ecological effects of enclosures, and land use assessment Enclosures enables both crop cultivation through protection from stray grazing animals and controlled rotational grazing. Eighty-nine percent of farmers in the four sample villages in Chepareria have enclosures on their farms $(n=80)$.

Almost all (99.2 \%) farmers with enclosures in four villages in Chepareria division $(n=120)$ combine livestock and some cultivation agriculture. However, $80 \%$ of the farm land is used for livestock and $20 \%$ for crops; the average farm size is 5.4 ha. Only one farmer depended on crop cultivation alone. Seventy-eight percent state that livestock is the most important component in their agricultural mix.

Soil organic carbon (SOC) was $30 \%$ higher in the top $20 \mathrm{~cm}$ inside enclosures as compared to outside $(p<0.05)$. This increase in SOC was consistent, although not significant (on the $p<0.05$ level), down to a soil depth of $80 \mathrm{~cm}$ for enclosures $<15$ years. The same pattern could not be observed in the older enclosures ( $>15$ years). This could be due to that the oldest enclosures were established on the worst areas initially (with extremely low SOC at the time) and/or that the management of these old enclosures had been neglected. There were no significant differences on the total carbon storage in tonne per hectare. Vegetation cover was found to be $40 \%$ higher inside enclosures than on adjacent open areas (Figure 4).

\section{Livestock}

Poultry was owned by $74 \%$ of the farmers, but not quantified. Average number of cattle and shoats, with quite high variation, among the 120 interviewed farmersis reported in Table 3 .

The importance of livestock was further underlined by the sales of animals during 2013 where $86 \%$ of the farmers with enclosures sold cattle and $87 \%$ sold goats. Compared to that, only $15 \%$ of the farms reported sale of milk. Only $34 \%$ sold crop grains (although $100 \%$ cultivated some maize) and $74 \%$ sold chicken. Of the average farm size of 5.4 ha, 4 ha was devoted to livestock production and 1 ha to crop production, while 0.4 ha was for house compound. Income from the sale of livestock is used as a buffer for large and unexpected costs, e.g. school costs. On average, livestock and livestockrelated production generated 2.5 times more annual income than crop agriculture. There have been introductions of new breeds of livestock by the Ministry of Agriculture. Both indigenous breeds (e.g. Zebu, Red Maasai sheep, East African goat) and crosses with exotic breeds (e.g. Holstein Friesian, Galla goat, Dorper sheep) were observed, but almost no pure exotic breeds.

\section{Enclosures and livelihood changes}

In all four villages studied, respondents associated the practice of enclosures with changing livelihood opportunities and constraints. Firstly, almost all interviews stress that livelihoods have become less dependent on livestock mobility in order to access pastures due to the enclosures and that livestock production is increasingly being complemented by production of crops. Secondly, enclosures are seen as instrumental in order for households to use land for agribusinesses that includes commercial livestock and agricultural production, and in some cases also the buying, selling and/ or renting of land. Thirdly, both male and female respondents especially highlighted the changing opportunities and constraints for women that have accompanied the introduction of enclosures in Chepareria. Traditionally, and in many cases still today, the role of women is defined as 'inside the community', having a more sedentary role close to the homestead than men. Men in contrast have been defined as being more mobile, 'moving inside and outside the community'. When the Vi Agroforestry started to introduce the practice of enclosures in the 1980s, the sedentary role 


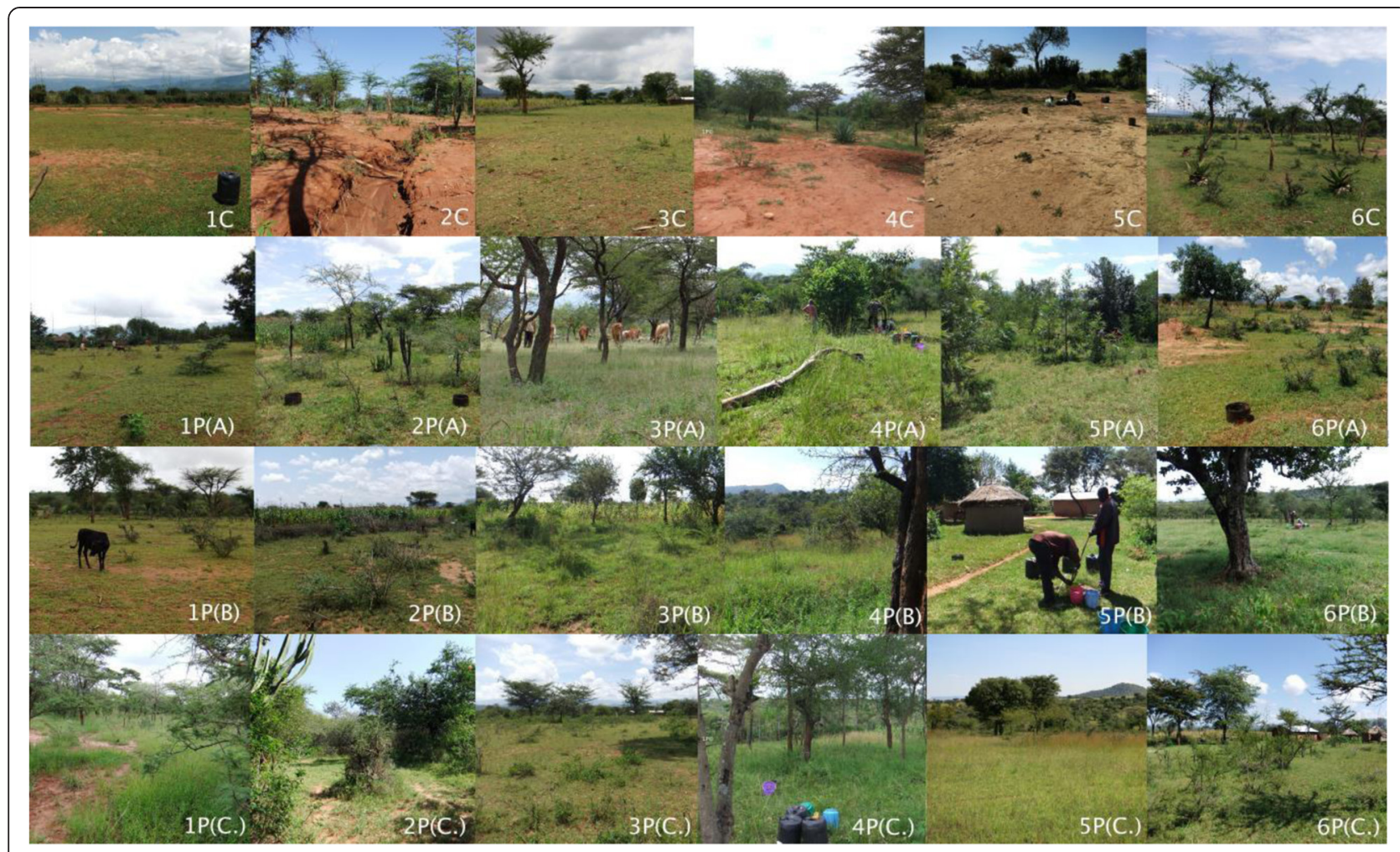

Figure 4 Photos from open and enclosed areas from the study on soil carbon and vegetation cover. C, control, open grazing; P, pasture, i.e. enclosed area; (A) 2- to 5-year-old enclosure; (B) 7 to 12 years old; (C.) $>15$ years old

of women 'inside the community', and their responsibility for household food subsistence, made them more willing to embrace the new land use techniques and eventually became early adapters of enclosures in the form of kitchen gardens. The narratives of land use transformation told by both male and female respondents indicate that the introduction and use of enclosures has contributed to increasing the status of women within the community and opening up for new, female-dominated livelihood strategies. For example, poultry production, which is not part of the traditional Pokot livelihood strategies, is today a livelihood activity dominated by women, providing an incomegenerating activity for $74 \%$ of the studied households. It was frequently referred to by the respondents as an activity that can be practised even by the poor and vulnerable in the community, owing to its low start-up costs and its short payback period.

The livelihood changes associated with enclosures depend on an ongoing privatization of land. Officially, land is registered under different statutory and customary tenure through individual title deeds, group ranches, trust land and government land. While the upper areas of Chepareria hold individual title deeds, the group ranches and trust land of the lower areas have and continuously continue to be sub-divided into privately enclosed land based on informal contractual agreements to secure their properties. On group ranches, residents are registered under group ranch title deeds that officially imply legitimate access to the whole group ranch land. However, as people have sub-divided and privatized group ranches with informal ownership agreements, people are not allowed to trespass on private properties and the enclosures work effectively as a demarcation of this property. The same conditions apply on trust land that is officially registered to allow for traditional communal tenure practices.

On group ranches and trust land, people expect and anticipate to be eventually issued official individual title deeds but not because of reasons for increased tenure security but to be eligible for bank loans. Along with the ongoing privatization of land comes its commodification. Our findings indicate the new phenomenon of an active land market in Chepareria. People sell or lease out parts of their land to earn money to cover school or medical costs, to purchase food during droughts or famine, or when they have few animals. Some people

Table 3 Farm size and livestock per household $(n=120)$

\begin{tabular}{lllll}
\hline & Mean & Min & Max & St.dev \\
\hline Farm size (ha) & 5.4 & 0.4 & 24.3 & 4.5 \\
Cattle & 8 & 0 & 42 & 7 \\
Shoats (=goats + sheep) & 21 & 2 & 96 & 17 \\
\hline
\end{tabular}


sell their whole land in order to purchase land in another, often more fertile, area, or to settle in town and start a business. In areas with title deeds, respondents mentioned that some people lease out their land to sustain themselves through financial means rather than to cultivate for subsistence.

However, the use of enclosures as part of an ongoing privatization of land does not only provide opportunities for new livelihood strategies. Many of the respondents told stories about people who do not have access to enclosed land and who have to resort to unsustainable harvesting of firewood on government land to make ends meet, and of emerging conflicts in the form of boundary disputes, livestock trespassing on enclosed land and internal family disputes related to land use and land ownership.

\section{Discussion}

In Machakos, land degradation and population pressure instigated a transformation to more commodified agriculture, including enclosures, in the 1950s, 1960s and 1970s (Jordan 1957; Pereira and Beckeley 1952; Tiffen et al. 1994), a transformation that was less degrading of the land as reflected in the title of Tiffen et al.'s book More People - Less Erosion. Although we did not measure erosion as such, we did measure some reciprocal parameters; the increases in vegetation cover and soil $\mathrm{C}$ inside enclosures, which were found by for example Damene et al. (2013) in Ethiopia and Mureithi et al. (2014) in another area of Kenya, as well as the increasing populations, and the extent of enclosure use in Chepareria, indicate that the title of Tiffen et al.'s book (1994) might be true also in this area.

The results presented above indicates that the increasingly common practice of enclosing land has taken place in parallel with a general increase in vegetation as well (as indicated by NDVI) from 2001 to 2014 in the two divisions included in the analysis. Furthermore, the increase is more significant in the Chepareria division, where the enclosing of land has a longer history and is more widely adopted. However, further studies are needed in order to empirically and systematically relate the practice of enclosures to the general increase in vegetation. This general increase in vegetation is however consistent with the results of our assessment of the ecological effects of enclosures, which shows that enclosures are associated with higher soil-organic carbon and vegetation cover than adjacent open grazing land. Although we did find significant increases in top soil $\mathrm{C}$ content, we cannot conclude that there was a change in total carbon storage since the bulk density of the soil from different depth and enclosure ages varied very much, and hence, the sampling procedure of this study, with six replicates and each replicate being the bulk of three sub- samples, might not have detected such changes. This implies that more sampling is needed to detect changes over time of total carbon storage, which is so much needed in the international $C$ sequestration discourse. The higher vegetation cover inside the enclosures provides a first indication that the practice of enclosing communal land in Chepareria and Kongelai has the potential to function as a management tool for sustainable dryland intensification (Angassa and Oba 2010; Catley et al. 2013; McDermott et al. 2010; Verdoodt et al. 2010; Woodhouse 2003). However, in order to move from indications to conclusions, these practices have to be followed for many years, through economic and management changes and through a time span of climatic variability, as well as include longitudinal data on vegetation composition and diversity.

We have furthermore been able to show that while an overwhelming majority of the farmers in the study area in Chepareria use the enclosures for a combination of livestock and crop production, livestock remains the most important component. We do also note that the relative success farmers have had with enclosures also leads to the need for new knowledge (e.g. technical, on management) that did not exist before. This accentuates the need for further development and research. In general, the study area seems to follow equilibrium rather than non-equilibrium dynamics (Derry and Boone 2010; von Wehrden et al. 2012) as indicated by the relative high precipitation (700 to $1,000 \mathrm{~mm} /$ year), the low CV of rainfall (around 20 according to Global map in von Wehrden et al. 2012) and the responsiveness to management. Rather than ecological concepts on equilibrium or non-equilibrium dynamics, concepts like risk aversion, diversification, management adaptability, resilience, robustness and sustainability (Accatino et al. 2014; Quaas et al. 2007; Robinson et al. 2015) might be more relevant in these de facto managed systems.

In addition, the results show that the practice of enclosing the land, in both direct and indirect ways, can be linked to socio-cultural, tenure and socio-economic changes in the study area. It seems to have formed an opportune part in the general local development towards increasing inclusion of the study area into an increasingly sedentary and monetary economy and subsequent changes in land use in order to meet the increasing demand for financial capital (Wairore et al. 2015a; Catley et al. 2013). The results also point at the importance of gender in relation to the practice of enclosures. Not only in terms of the importance of women as early adapters of enclosure management, but also how the introduction of enclosures has contributed to the emergence of a 'female economy' that has increased women's economic status. This development is in line with a general development trajectory in pastoralist East Africa, where 
households find themselves in a situation where both genders need to contribute in all possible ways to the household economy through cash-generating activities (Wangui 2014). Nevertheless, while women have gained increased decision-making as well as economic power in many areas of life, the livestock with the highest economic value, cattle, is still a male space.

Furthermore, our results points at a complex process where privatization does not necessarily imply private land ownership, and which at least temporarily, provides space for the co-existence of land under formal, private title deeds; privately tenured land under communal ownership; and land under communal tenure and ownership (Lesorogol 2008).

\section{Conclusion}

Overall, the analysis presented in this paper offers an empirically-based example that speaks to the generally assumed trajectory from nomadic, subsistence-based pastoralism towards sedentary, market-oriented, agropastoralist production systems (Delgado et al. 1999; McDermott et al. 2010; Sumberg and Thomson 2013). As such, it adds to the present lack of multi-disciplinary insights from context-specific development dynamics in pastoralist, dryland areas in East Africa.

On the one hand, and confirming previous studies, enclosures seem to provide opportunities for a more productive and profitable livestock production where diversified income streams are possible, and at the same time contribute to increased vegetation cover and soil organic carbon (e.g. Mureithi et al. 2015). Furthermore, enclosures seem to form part of rapid and, in most parts, positive change in gender relations. On the other hand, the practice of enclosures is also related to emerging conflicts and inequalities in relation to land. However, in order to more firmly and systematically assess the sustainability outcomes of enclosures and the ongoing transition towards sedentary, market-based agro-pastoralist livelihoods, further studies are needed. The analysis does however illustrate the importance of recognizing and accounting for local, alternative pathways and strategies within the general transition. We argue that it is the room for and nature of such local pathways and strategies that will determine the sustainability outcomes of the ongoing transition and land use transformation in dryland areas across East Africa.

The transformation from pastoralism to a livestockbased agro-pastoral system, where enclosures are an integrated part of the land use management, may hence represent a sustainable and productive development and transformation that could be a valid way forward in many dryland areas, especially in sub-Saharan Africa.

\footnotetext{
Abbreviations

C: Carbon; $\mathrm{CO}_{2}$ eq: Carbon dioxide equivalents; Gt: Gigatonne; NGO: Nongovernmental organization; SSA: Sub-Saharan Africa.
}

\section{Competing interests}

The authors declare that they have no competing interests.

\section{Authors' contributions}

GN and PK wrote most of the text. GN, PK, MO, IO, EW, MJ, PW, SM, MS, DO and AM planned and structured the manuscript, all of whom also contributed with comments and suggestions during the writing. AG, JW, SS, LS, LG, VK, JW and RW carried out individual minor research projects under the supervision of some of the above group. They also checked that data interpretation and the writing on respective fields was correct and contributed comments in general. JDW contributed heavily to the final writeup with comments and constructive suggestion. All the authors have read and approved the final draft of this manuscript.

\section{Acknowledgements}

We are grateful to the Triple $L$ Research Initiative for initiated this research and to Swedish Ministry of Foreign Affairs (through UD20), SLU Global and International Livestock Research Institute (ILRI) for funding of this research. We are also grateful to Vi Agroforestry for assistance in the field and to the farmers interviewed and for allowing us sample their farms.

\section{Author details}

'Department of Forest Ecology and Management, SLU, SE-901 83 Umeå, Sweden. ${ }^{2}$ School of Global Studies, University of Gothenburg, Box 700, SE-40530 Göteborg, Sweden. ${ }^{3}$ Centre for Environment and Sustainability, University of Gothenburg/Chalmers University of Technology, 40530 Göteborg, Sweden. ${ }^{4}$ Centre for Climate Science Policy Research, Linköping University, 58183 Linköping, Sweden. ${ }^{5}$ Department Crop Production Ecology, SLU, P.O. Box 7043, SE-750 07 Uppsala, Sweden. ${ }^{6}$ World Agroforestry Centre (ICRAF), UN Avenue, P.O. Box 30677-00100, Nairobi, Kenya. ${ }^{7}$ Department Animal Nutrition and Management, SLU, P.O. Box 7024, SE-750 07 Uppsala, Sweden. ${ }^{8}$ Department of Agricultural Economics, University of Nairobi, P.O. Box 29053, Nairobi 00625, Kenya. ${ }^{9}$ Department of Land Resource Management and Agricultural Technology, University of Nairobi, P.O. Box 29053, Nairobi 00625, Kenya. ${ }^{10}$ Department of Botany, Jomo-Kenyatta University of Agriculture and Technology, P.O. Box 62000-00200, Nairobi, Kenya. ${ }^{11}$ International Livestock Research Institute, P.O. Box 30709-00100, Nairobi, Kenya. ${ }^{12}$ Department of Human Geography, Lund University, Box 117, 22100 Lund, Sweden. ${ }^{13}$ Department of Food and Resource Economics (IFRO), University of Copenhagen, Rolighedsvej 25, 1958 Frediksberg C, Denmark.

Received: 26 March 2015 Accepted: 6 October 2015

Published online: 03 December 2015

\section{References}

Accatino, F, R Sabatier, C De Michele, D Ward, K Wiegand, and KM Meyer. 2014. Robustness and management adaptability in tropical rangelands: A viability-based assessment under the non-equilibrium paradigm. Animal 8: 1272-1281.

Angassa, A, and G Oba. 2008. Herder perceptions on impacts of range enclosures, crop farming, fire ban and bush encroachment on the rangelands of Borana, Southern Ethiopia. Human Ecology 36: 201-215.

Angassa, A, and G Oba. 2010. Effects of grazing pressure, age of enclosures and seasonality on bush cover dynamics and vegetation composition in southern Ethiopia. Journal of Arid Environments 74: 111-120.

Ayantunde, A, J de Leeuw, MD Turner, and M Said. 2011. Challenges of assessing the sustainability of (agro)-pastoral systems. Livestock Science 39: $30-43$.

Aynekulu, E, T-G Vagen, K Shepherd, and L Winowiecki. 2011. A protocol for measurement and monitoring soil carbon stocks in agricultural landscapes. Version 1.1. Nairobi: World Agroforestry Centre.

Barrow, E. 2014. Shinyanga Forest: Retrofitting resilience to the Shinyanga Forest landscape restoration case study. IUCN (International Union for Conservation of Nature). http://cmsdata.iucn.org/downloads/shinyanga_forest.pdf. Accessed 20 Feb 2015.

Bernstein, H, D Hulme, and P Woodhouse. 2003. African enclosures? The social dynamics of wetlands in drylands. Africa: Journal of the International African Institute 73(1): 141-142. Cambridge University Press. 
Beyene, F. 2009. Exploring incentives for rangeland enclosures among pastoral and agropastoral households in eastern Ethiopia. Global Environmental Change 19: 494-502.

Beyene, F. 2010. Locating the adverse effects of rangeland enclosure among herders in eastern Ethiopia. Land Use Policy 27: 480-488.

Beyene, F. 2014. Determinants of food security under changing land use systems among pastoral and agro-pastoral households in eastern Ethiopia. Environment, Development and Sustainability 1-20

Briske, DD, SD Fuhlendorf, and FE Smeins. 2003. Vegetation dynamics on rangelands: A critique of the current paradigms. Journal of Applied Ecology 40: 601-614.

Bryman, A. 2012. Social research methods, 4th ed. Oxford: Oxford University Press.

Campbell, A, L Miles, I Lysenko, A Huges, and H Gibbs. 2008. Carbon storage in protected areas. Technical report. UNEP World Conservation Monitoring Center, Cambridge.

Catley, A, J Lind, and I Scoones (eds.). 2013. Pathways to sustainability: Pastoralism and development in Africa. Dynamic change at the margins. Abingdon: Earthscan from Routledge.

County Government of West Pokot. 2013. First county integrated development plan 2013 -2017. http://www.westpokot.go.ke/images/downloads/ CIDPfinaldraft.pdf. Accessed 5 Nov 2015.

Damene, S, L Tamene, and PLG Vlek. 2013. Performance of exclosure in restoring soil fertility: A case of Gubalafto district in North Wello Zone, northern highlands of Ethiopia. Catena 101: 136-142.

Delgado, C, M Rosegrant, H Steinfeld, S Ehui, and C Curbois. 1999. Livestock to 2020. The next food revolution. Food, Agriculture and Environment Discussion Paper 28. Washington DC: International Food Policy Research Institute.

Derry, JF, and RB Boone. 2010. Grazing systems are a result of equilibrium and non-equilibrium dynamics. Journal of Arid Environments 74: 307-309.

Fensholt, R, and SR Proud. 2012. Evaluation of earth observation based global long term vegetation trends-Comparing GIMMS and MODIS global NDVI time series. Remote Sensing of Environment 119: 131-147.

Gichero, P, S Nabwile Makokha, Le Chen, L Gachimbi, and J Wamuongo. 2012. Land subdivision and degradation in Narok, Kenya. In Land use policies for sustainable development. Exploring integrated assessment approaches, ed. D McNeil, I Nesheim, and F Brouwer. Cheltenham: Edward Elgar Publishing Limited.

Greiner, C, M Alvarez, and M Becker. 2013. From cattle to corn: Attributes of emerging farmer systems of former pastoral nomads in East Pokot, Kenya. Society and Natural Resources: An International Journal 26(12): 1478-1490.

Hardin, G. 1968. The tragedy of the commons. Science 162: 1243-1248.

Havlik, P, H Valin, M Herrero, E Schmid, MC Rufino, A Mosnier, PK Thornton, H Böttcher, RT Contant, S Frank, S Fritz, S Fuss, F Kraxner, and A Nortenbaeert. 2014. Climate change mitigation through livestock system transitions. PNAS 111(10): 3709-3714.

Herrero, M, D Grace, J Njuki, N Johnson, D Enahoro, S Silvestri, and MC Rufino. 2012. The roles of livestock in developing countries. Animal 7(s1): 3-18.

Jordan, SM. 1957. Reclamation and pasture management in the semi-arid areas of Kitui District. East African Agriculture and Forestry Journal 23: 84-88.

Kitalyi, A, A Musili, J Suazo, and F Ogutu. 2002. Enclosures to protect and conserve. For better livelihood of the West Pokot community. RELMA Technical Pamphlet Series No. 2. Nairobi: Regional Land Management Unit.

Lal, R. 2004. Sequestering carbon in soils of arid ecosystems. Land Degradation and Development 20(4): 441-454.

Lambin, E, H Geist, and E Leepers. 2003. Dynamics of land-use and land-cover change in tropical regions. Annual Review of Environmental Resources 28: 205-241.

Lesorogol, Carolyn K. 2008. Land privatization and pastoralist well-being in Kenya. Development and Change 39(2): 309-331.

Makokha, W, S Lonyakou, M Nyang, KK Kareko, C Holding, TJ Njoka, and A Kitalyi. 1999. We work together: Land rehabilitation and household dynamics in Chepareria Division West Pokot, Kenya. Technical Report, RELMA and Vi Agroforestry Project Kitale-Kenya, Kitale. Kitale: SIDA's regional land management unit.

McDermott, J, S Staal, H Freeman, M Herrero, and J Van de Steeg. 2010. Sustaining intensification of smallholder livestock systems in the tropics. Livestock Science 130: 95-109.

Mekuria, W, E Veldkamp, MD Corre, and M Haile. 2011. Restoration of ecosystem carbon stocks following exclosure establishment in communal grazing lands in Tigray, Ethiopia. Soil Science Society of America Journal 75(1): 246-256.
Monela, GC, SAO Chamshama, R Mwaipopo, and DM Gamassa. 2005. A study on the social, economic and environmental impacts of forest landscape restoration in Shinyanga Region, Tanzania. IUCN (International Union for Conservation of Nature) http://cmsdata.iucn.org/downloads/flr_final_report_ shinyanga_june2005.pdf. Accessed 20 Feb 2015

Moritz, M. 2012. Pastoralist intensification in West Africa. Implications for sustainability. Journal of the Royal Anthropological Institute 18(2): 418-438.

Mortimore, M, Anderson, S, Cotula, L., Davies, J.,Faccer, K., Hesse, C., Morton, J., Nyangena, W., Skinner, J. and Wolfangel, C. 2009. Dryland opportunities: A new paradigm for people, ecosystems and development. IUCN, Gland, Switzerland; IIED, London, UK and UNDP/DDC, Nairobi, Kenya. (http://data.iucn.org/dbtw-wpd/edocs/2009-033.pdf)

Müller, B, K Frank, and C Wissel. 2007. Relevance of rest periods in non-equilibrium rangeland systems - A modelling analysis. Agricultural Systems 92: 295-317.

Mureithi, SM, S Verdoodt, KK Gachene, JT Njoka, VO Wasonga, S De Neve, E Meyerhoff, and E Van Ranst. 2014. Impact of enclosure management on soil properties and microbial biomass in a restored semi-arid rangeland, Kenya. Journal of Arid Land 6(5): 561-570.

Mureithi, SM, A Verdoodt, JT Njoka, CKK Gachene, and E Van Ranst. 2015. Benefits derived from rehabilitating a degraded semi-arid rangeland in communal enclosures, Kenya. Land Degradation \& Developlopment doi:10.1002/ldr.2341

Mwangi, E. 2007. The puzzle of group ranch subdivisions in Kenya's Maasailand. Develoment and Change 35(5): 889-910.

Napier, A, and S Desta. 2011. Review of pastoralist rangeland enclosures in Ethiopia. Feinsteain International Centre and Tufts University, November 2011, Addis Abeba. http://fic.tufts.edu/assets/Tufts-Range-Enclosure-ReviewPLI.pdf. Accessed 26 Sep 2015

NDMA. National Drought Management Authority West Pokot County. Drought monthly bulletin for July 2014. Available at: http://reliefweb.int/sites/ reliefweb.int/files/resources/West_Pokot-July-2014.pdf. Accessed 15 Dec 2014

Neely, C, S Bunning, and A Wilkes (eds.). 2009. Review of evidence on drylands pastoral systems and climate change: Implications and opportunities for mitigation and adaptation. FAO. The United Nations, Rome.

Opiyo, FEO, WN Ekaya, DM Nyariki, and SM Mureithi. 2011. Seedbed preparation influence on morphometric characteristics of perennial grasses of a semi-arid rangeland in Kenya. African Journal of Plant Sciences 5(8): 460-468.

Ostwald, M, E Simelton, D Chen, and A Liu. 2007. Relation between vegetation changes, climate variables and land-use policy in Shaanxi Province, China. Geografiska Analer 89: 223-236.

Pereira, HC, and VRS Beckeley. 1952. Grass establishment on eroded soil in a semi-arid African reserve. Empire Journal of Experimental Agriculture 21: 11-14.

Quaas, MF, S Baumgärtner, C Becker, K Frank, and B Müller. 2007. Uncertainty and sustainability in the management of rangelands. Ecological Economics 62: 251-266.

Robinson, LW, PJ Ericksen, S Chesterman, and JS Worden. 2015. Sustainable intensification in drylands: What resilience and vulnerability can tell us. Agricultural Systems 135: 133-140.

Schmidt, M, and O Pearson. 2016. Pastoralist livelihoods under pressure: Ecological, political and socio-economic transitions in Afar (Ethiopia). Journal of Arid Environments 124: 22-30.

Smith, P, D Martino, Z Cai, D Gwary, HH Janzen, P Kumar, B McCarl, S Ogle, F O'Mara, C Rice, B Scholes, and O Sirotenko. 2007. Agriculture. In Climate Change 2007: Mitigation. Contribution of Working Group III to the Fourth Assessment Report of the Intergovernmental Panel on Climate Change. Cambridge, United Kingdom and New York, NY, USA: Cambridge University Press.

Stohlgren, TJ, MB Falkner, and LD Schell. 1995. A modified-Whittaker nested vegetation sampling method. Vegetation 117(2): 113-121.

Sumberg, J, and J Thomson. 2013. STEPS Working Paper 52. Brighton: STEPS Centre. Revolution reconsidered: Evolving perspectives on livestock production and consumption.

Thomas, AD. 2012. Impact of grazing intensity on seasonal variations in soil organic carbon and soil $\mathrm{CO}_{2}$ efflux in two semiarid grasslands in southern Botswana. Philosophical Transactions of the Royal Society B 367: 3067-3086.

Thornton, P. 2010. Livestock production: recent trends, future prospects. Philosophical Transactions of the Royal Society B 365: 2853-2867.

Tiffen, M, M Mortimore, and F Gichuki. 1994. More people, less erosion: environmental recovery in Kenya. New York: Wiley.

UNEP. 2008. Carbon in drylands: Desertification, climate change and carbon finance. Istanbul: A UNEP- UNDP-UNCCD Technical Note for Discussions at CRIC 7. 03-14 November, 2008. 
Group, United Nations Environment Management. 2011. Global drylands: A UN system-wide approach. The United Nations.

Verdoodt, A, SM Mureithi, and E Van Ranst. 2010. Impacts of management and enclosure age on recovery of the herbaceous rangeland vegetation in semi-arid Kenya. Journal of Arid Environments 74: 1066-1073.

Vetter, S. 2005. Rangeland at equilibrium and non-equilibrium: recent developments in the debate. Journal of Arid Environments 62: 321-341.

Von Wehrden, H, J Hanspach, P Kaczensky, J Fischer, and K Wesche. 2012. Global assessment of the non-equilibrium concept in rangelands. Ecological Applications 22(2): 393-399.

Wairore, JN, ST Mureiti, OV Wasonga, and G Nyberg. 2015a. Benefits derived from rehabilitating a degraded semi-arid rangeland in private enclosure in West Pokot County, Kenya. Land Degradation \& Development. doi:10.1002/ldr.2420

Wairore, JN, ST Mureiti, OV Wasonga, and G Nyberg. 2015b. Characterization of enclosure management regimes and factors influencing their choice among agropastoralists in North-Western Kenya. Pastoralism: Research, Policy and Practice 5: 14. doi:10.1186/s13570-015-0036-7

Wangui, E. 2014. Livelihood shifts and gender performances: Space and the negotiation for labor among east Africa's pastoralists. Annals of the Association of American Geographers 104(5): 1068-1081.

Woodhouse, P. 2003. African enclosures: A default mode of development. World Development 31(10): 1705-1720.

Yaynshet, T, LO Eik, and SR Moe. 2009. The effects of exclosures in restoring degraded semi-arid vegetation in communal lands in northern Ethiopia. Journal of Arid Environments 73: 542-549.

\section{Submit your manuscript to a SpringerOpen ${ }^{\circ}$ journal and benefit from:}

- Convenient online submission

- Rigorous peer review

- Immediate publication on acceptance

Open access: articles freely available online

- High visibility within the field

- Retaining the copyright to your article

Submit your next manuscript at $>$ springeropen.com 